\title{
Etiology of Pediatric Jaundice: Observation in the Pediatric Ward of the Gabriel Toure University Hospital
}

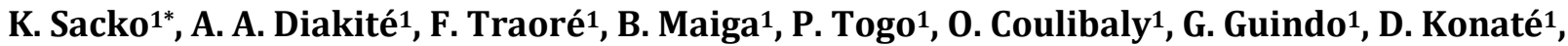 \\ A. K. Doumbia' ${ }^{1}$, H. Konaré1, S. Sagara ${ }^{1}$, A. Dembélé1, A. Touré1, F. L. Diakité1, L. N. Sidibé1,

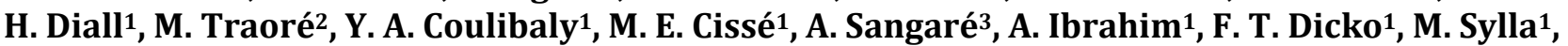 \\ B. Togo ${ }^{1}$
}

${ }^{1}$ Pediatric Department of Gabriel Toure University Hospital, Bamako, Mali

${ }^{2}$ Pediatric Service of the Reference Health Center of Municipality 5, Bamako, Mali

${ }^{3}$ Pediatric Service of the Mali Hospital, Bamako, Mali

Email: ^Karamoko_sacko@yahoo.fr

How to cite this paper: Sacko, K., Diakité, A.A., Traoré, F., Maiga, B., Togo, P., Coulibaly, O., Guindo, G., Konaté, D., Doumbia, A.K., Konaré, H., Sagara, S., Dembélé, A., Touré, A., Diakité, F.L., Sidibé, L.N., Diall, H., Traoré, M., Coulibaly, Y.A., Cissé, M.E., Sangaré, A., Ibrahim, A., Dicko, F.T., Sylla, M. and Togo, B. (2020) Etiology of Pediatric Jaundice: Observation in the Pediatric Ward of the Gabriel Toure University Hospital. Open Journal of Pediatrics, 10, 759-768. https://doi.org/10.4236/ojped.2020.104077

Received: November 3, 2020

Accepted: December 28, 2020

Published: December 31, 2020

Copyright $\odot 2020$ by author(s) and Scientific Research Publishing Inc. This work is licensed under the Creative Commons Attribution International License (CC BY 4.0).

http://creativecommons.org/licenses/by/4.0/

\begin{abstract}
Objective: Pediatric jaundice is caused by various conditions. Although some data is available on this issue, data from Mali is insufficient. The present retrospective observational study was an attempt to determine the etiology of pediatric jaundice in the pediatric department of Gabriel Touré teaching hospital in Bamako, Mali. Methods: We reviewed all pediatric patients with jaundice who were hospitalized and treated in this department during January 1 to December 31, $2016(n=168)$. Result: Pediatric jaundice patients accounted for $1.88 \%$ of the hospitalized patients, with median age of 6 years and male/female ratio being 1.6. Infectious, cholestatic, and hemolytic jaundice accounted for $75 \%, 11 \%$ and $10 \%$, respectively. Malaria and sickle cell disease accounted for $67 \%$ and $9 \%$, respectively. Hepatomegaly and splenomegaly were observed in 49 (29\%) and $23(13.7 \%)$ patients, respectively. Of 168, 9 patients died. Conclusion: Infectious jaundice, especially jaundice due to malaria, was the most frequent. However, variety of etiologies was observed, of which the practitioners should be aware. The observation presented here may become fundamental data in health-policy making in this area.
\end{abstract}

\section{Keywords}

Jaundice, Etiology, Paediatrics, Mali

\section{Introduction}

Jaundice is one of the reasons for frequent consultation in pediatrics. It is often 
reported by parents. At times, it is observed by the pediatrician due to the existence of another clinical symptom evoking a liver disease or hemolytic [1]. In practice, the pediatrician often comes across one of these following four situations: jaundice and stool discoloration, jaundice, haemolysis and isolated jaundice [2] [3]. Jaundices etiologies are many; we can divide them into two big categories according to the increase of serum bilirubin which can be non-conjugated bilirubin or conjugated bilirubin and of mixed cause as well [1].

In Mali, we don't have statistics related to child and infant's jaundice, which is the reason why we conducted this study of the infant and child's jaundices etiologies in the paediatric ward at Gabriel Toure university hospital centre.

\section{Methods and Patients}

It was a prospective study led from $1^{\text {st }}$ January to $31^{\text {st }}$ December 2016 (12 months) in the paediatric ward of the university hospital centre of Gabriel Toure. The university hospital center of Gabriel Toure is a third reference hospital in the Bamako city, Mali's capital, sahelo-saharan country. All infants and hospitalized children in the ward with icterus were included at the entry examination witin the study. The parameters studied within the searching were: anamnestic, clinical, paraclinical, treatment and scalable. The data were collected on a survey sheet, entered by Word and Excel software and then analyzed by SPSS version 20 software.

\section{Results}

During the study we collected 168 files of infants and children with jaundice out of 8924 hospitalization or a frequency of $1.8 \%$.

\subsection{Soci-Demographic Data}

The average age was 6 years and 3 months with a standard deviation of 4 years and the median age was 6 years. The most represented age group was from 1 to 5 years old with $39.5 \%$ (66 patients). The male sex predominated with $62.5 \%$, the sex ratio was $1.66 \%$. Patients from outside Bamako accounted for $42.9 \%$.

\subsection{Clinical Data}

The vaccination according to Mali's Expanded Program on Immunization (EPI) was up to date in $65 \%$ of patients and $15.5 \%$ had been hospitalized for at least one year. We found $1^{\text {st }}$ degree consanguinity in 126 patients (75\%), the notion of jaundice was found in $20(11.9 \%)$ and 7 (4.1\%) were known to have sickle cell disease.

Anemia and fever were the most common reasons for consultation with $26.7 \%$ and $23.8 \%$ respectively. Icterus was the reason for consultation in $13 \%$ of patients. At the entrance clinical examination, $81 \%$ of patients presented with fever, $42.8 \%$ with digestive disorders and $20.82 \%$ with abdominal pain. Feces were discolored in $5.35 \%$ of patients and urine was dark in $6.5 \%$. Jaun- 
dice was generalized in 112 patients (66.6\%), limited to the conjunctiva in 40 (23.8\%) and a subicterus in 18 (10.7\%). The general condition was poor in 79 patients (47\%), pallor was found in $140(83.3 \%)$, hepatomegaly in $49(29 \%)$ and splenomegaly in 23 (13.6\%. Infectious jaundice class predominated with $75 \%$ followed by cholestatic jaundice (11\%) and constitutional hemolytic jaundice (10\%) (Table 1).

The hemogram was performed at $97 / 168$. The majority of patients (95\%) had an anemia (Hemoglobin $\leq 11 \mathrm{~g} / \mathrm{dl}$ ) that was microcytic (average globular volume $<70$ fintolitre) in $62 \%$. Hyperleukocytosis (WBC $>10,000 / \mathrm{mm}^{3}$ ) was found in $41 \%$ of patients and leukopenia in $4 \%$. Increased in 56/72 patients and conjugated bilirubin ( $\mathrm{VN} \leq 5 \mu \mathrm{mol} / \mathrm{L}$ ) was elevated in $21 / 72$ patients. Transaminases were achieved in 33/168 patients with elevated AST in 27/33 and increased ALT in $24 / 33$. GGTs were increased in $14 / 18$ patients and alkaline phosphatases were

Table 1. Clinical characteristics.

\begin{tabular}{|c|c|c|}
\hline Clinicla characteristics & Number & Percentage \\
\hline \multicolumn{3}{|c|}{ Age group } \\
\hline$<1$ year & 16 & 9.6 \\
\hline 1 to 5 ans & 66 & 39.5 \\
\hline 5 to 10 years & 52 & 31.1 \\
\hline \multirow{2}{*}{$>10$ years } & 33 & 19.8 \\
\hline & Sex & \\
\hline Male & 105 & 62.5 \\
\hline Female & 63 & 37.5 \\
\hline \multicolumn{3}{|c|}{ Anamnestic signs } \\
\hline Dark urine & 11 & 6.54 \\
\hline Discolored stools & 9 & 5.35 \\
\hline Fever & 136 & 81 \\
\hline Digestive disorders & 72 & 42.85 \\
\hline Abdominal pain & 35 & 20.83 \\
\hline pruritus & 2 & 1.19 \\
\hline \multicolumn{3}{|c|}{ Physical signs } \\
\hline Poor general condition & 79 & 47 \\
\hline Skin rashes & 4 & 2.38 \\
\hline Pallor & 140 & 83.33 \\
\hline jaundice & 168 & 100 \\
\hline Hepatomegaly & 49 & 29.16 \\
\hline Splenomegaly & 23 & 13.69 \\
\hline Abdominal mass & 4 & 2.38 \\
\hline Ascites & 3 & 1.78 \\
\hline $\mathrm{CVC}$ & 2 & 1.19 \\
\hline
\end{tabular}


elevated in 10/15 patients. Thick Drop was the most requested diagnostic adjunct test and was positive in $67 \%$ of patients. Hepatitis A serology was positive in $7 \%$ of patients and $\mathrm{Hbs} \mathrm{Ag}$ was positive in $4 \%$. Abdominal ultrasonography was performed in 45/168 patients and showed hepatomegaly in 15 , splenomegaly in 6 and others (Table 2 and Table 3 ).

The etiologies were dominated by malaria (67\%), Sickle cell anemia (9\%), hepatitis A (7\%) and hepatitis B (4\%). Other etiologies such as bile duct atresia, hepatic abscess and pneumonia were found but in very low proportions (Figure 1).

Table 2. Biological charateristics.

\begin{tabular}{|c|c|c|}
\hline Parametres & Number & Percentage \\
\hline \multicolumn{3}{|c|}{ Total Bilirubin $(\mathrm{n}=72)$} \\
\hline High & 72 & 100 \\
\hline Normal & 0 & 0 \\
\hline \multicolumn{3}{|c|}{ Conjugated Bilirubin $(n=72)$} \\
\hline High & 21 & 29 \\
\hline Normal & 51 & 71 \\
\hline \multicolumn{3}{|c|}{ Free Bilirubin $(n=72)$} \\
\hline High & 56 & 78 \\
\hline Normal & 16 & 22 \\
\hline \multicolumn{3}{|l|}{$\operatorname{AST}(n=33)$} \\
\hline Normal & 6 & 18 \\
\hline High & 27 & 82 \\
\hline \multicolumn{3}{|l|}{$\operatorname{ALT}(\mathrm{n}=33)$} \\
\hline Normal & 9 & 27.3 \\
\hline High & 24 & 72.7 \\
\hline \multicolumn{3}{|c|}{ Alkaline Phosphatase $(n=15)$} \\
\hline Low & 5 & 14 \\
\hline High & 10 & 86 \\
\hline \multicolumn{3}{|c|}{ Gamma Glutamine Transferase $(\mathrm{n}=18)$} \\
\hline Normal & 4 & 8 \\
\hline High & 14 & 92 \\
\hline \multicolumn{3}{|c|}{ Prothrombin time $(\mathrm{n}=17)$} \\
\hline Normal & 17 & 100 \\
\hline Collapsed & 0 & 0 \\
\hline \multicolumn{3}{|c|}{ Thick Drop $(\mathrm{n}=99)$} \\
\hline positive & 67 & 68 \\
\hline negative & 32 & 32 \\
\hline \multicolumn{3}{|c|}{ Serology hepatitis A $(n=9)$} \\
\hline Positive & 7 & 78 \\
\hline Negative & 2 & 22 \\
\hline \multicolumn{3}{|l|}{$\mathrm{Ag} \mathrm{Hbs}(\mathrm{n}=5)$} \\
\hline Positive & 4 & 80 \\
\hline Negative & 1 & 20 \\
\hline
\end{tabular}




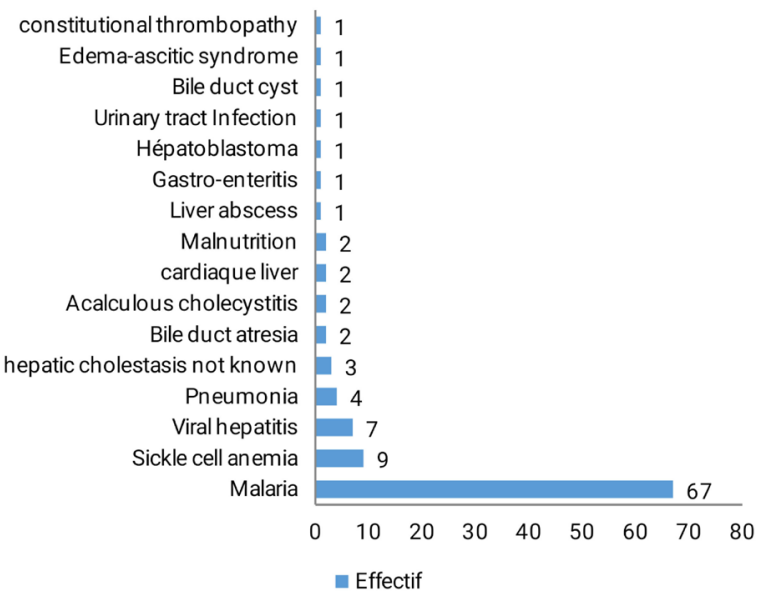

Figure 1. Distribution of patients according to etiologies.

Table 3. Distribution of patients according to jaundice classes.

\begin{tabular}{ccc}
\hline Class jaundice & Number & Percentage \\
\hline Infectious jaundice & 126 & 75 \\
Cholestatic jaundice & 18 & 10.7 \\
Constitutional hemolytic jaundice & 16 & 9.5 \\
Isolated jaundice & 8 & 5.4 \\
Total & 168 & 100.0 \\
\hline
\end{tabular}

A cure had been observed in 139 patients, 12 were discharged against medical advice, 9 were deceded and 8 are being followed up.

\section{Discussion}

Jaundice in infants and children has been a little studied in Africa. As a result, few references have been found in Mali and Africa to discuss our findings.

The frequency of $1.8 \%$ was relatively high given the different etiologies likely to cause jaundice in children in our context of malaria-endemic countries.

The average age was 6 years and 3 months and the most common age group was 1 to 5 years with $39.5 \%$ ( 66 patients). Given that infectious etiologies were the most common, the high frequency (39.5\%) of the $1-5$ year age group could be explained by their vulnerability to infection. The average age of 6.3 of our series was close to that of the study carried Morocco in 2010 on the febrile icteres of the child who found an average age of $6.1 \pm 3$ year, with a median age of 5.5 years (extreme: 1 - 15 years) and children under the age of six were the most affected with $51.7 \%$ [4] [5]. The sex ratio was 1.6 in our study, this predominance of the male sex had been reported by several authors [2] [5].

Anemia and fever were the most common reasons for consultation with $26.7 \%$ and $23.8 \%$ respectively, and jaundice was the reason for consultation for $13 \%$ of patients. The association of icterus with fever is much found in infectious diseases such as malaria which the etiology the most common in our searching. 
Anemia can be explained by hemolysis, which is due to infectious pathologies, in this case malaria, and to certain constitutional pathologies such as drepanocytosis (sickle cell disease).

At the entrance clinical examination, $81 \%$ of the patients had a fever, $42.8 \%$ had digestive problems and $20.8 \%$ had abdominal pain. All of these signs are found in the infectious syndrome, which remains the most common etiological group in our study.

Feces were discoloured in 5.3\% of patients and dark urine in $6.5 \%$. The association of jaundice with coloured feces and dark urine evokes a cholestatic jaundice.

A hepatomegaly is most often a sign of hepatic suffering, its discovery most often leads to an infectious or cholestatic jaundice and requires an etiological assesment. It was found in $29 \%$ of our patients.

The predominance of infectious jaundice (75\%) could be expalained by the poor hygienic conditions and especially by the fact that the study site is a malaria endemic zone.

The anemia found in $95 \%$ of patients could be explained by a high prevalence of martial deficiency in the pediatric population where the microcytosis $(62 \%)$. According to Demographic and health survey-Mali V, $82 \%$ of children aged 6 to 59 months suffer from anemia [6].

The low rate of realisation of serum bilirubin (72/168) could be explained by the low income of the parents, free bilirubin was increased in 56/72 and conjugated bilirubin was increased in 21/72. Transaminases were carried out in 33/168 patients with high asparate aminotransferase in $27 / 33$ and increased alamin aminotransferase in 24/33 explaining hepatic suffering due to hepatocyte damage. GGTs were increased in 14/18 patients and PALs were elevated in 10/15. This increase in GGTs points towards a cholestatic ictere.

The thick drop was the complementary examination aimed at the most requested diagnosis and was positive in $67 \%$ of patients, in our context every feverish patient is given a thick drop to confirm or rule out malaria. The etiologies were dominated by malaria (67\%) followed by drepanocytosis (9\%), hepatitis A (7\%) and hepatitis B (4\%). Other aetiologies such as biliary (tract) atresia, hepatic abscess and pneumonia were found but in very low proportions. In Morocco the etiologies are dominated by G6PD (glucose 6 phosphatase deshydrogenase) deficiency (18\%), Wilson's disease (18\%) and hepatitis A (15\%) [7]. Other studies carried out on the etiologiy of febrile jaundice had found hepatitis $\mathrm{A}$ as the first etiology with 91.5\% [5] [8] [9] [10]. These results show a difference in the etiology of the jaundice between these two regions in Africa. In Mali, malaria is the first cause of death and death among children under 5 years, which represent $40 \%$ of the first cause of consultation in public health facility according to the health facility system data and its national prevalence is estimated to $52 \%$ [6].

\section{Conclusion}

Jaundice is a frequent sign in infants and children, the infectious etiologies are 
more frequent and dominated by malaria. Other etiologies such as sickle cell anemia and cholestatic jaundice (Bile duct atresia) should not be forgotten. The treatment is especially etiologic and the progress beneficial if the etiological support is premature and fitted.

\section{Conflicts of Interest}

The authors declare no conflicts of interest regarding the publication of this paper.

\section{References}

[1] Rambaud, P. (2005) Neonatal Jaundice. Medical Corpus. http://www-sante.ujf-grenoble.fr/SANTE/corpus/disciplines/pedia/nouveaune/320/1 econ320.htm

[2] Frexinos, J. (1988) Clinical Hepato-Gastroenterology. 4e Edition, Simep, 454 p.

[3] Lacaille, F. and Lachaux, A. (2010) Liver and Biliary Tract Disease in Children. 1st Edition, Wolters Kluvers, France, 410 p.

[4] Benhamou, J.P., Sarles, H. and Gerolami, A. (1890) Liver, Pancreas and Biliary Tract. 2e edition, Flammarion, Paris, 227 p.

[5] Bourrousa, M., Draisa, G., Amineb, M., Adabbousa, A., Admouc, I. and Bouskraouia, M. (2010) Seroprevalence of Viral Hepatitis A in Febrile Jaundice in Children of Marrakech, Maroc. Diary of Pediatrics Childcare, 23, 76-81.

https://doi.org/10.1016/j.jpp.2009.09.007

[6] Institut National de la Statistique (INSTAT) (2018) Planning and Statistics Unit for the Health-Social Development and Family Promotion Sector. Sixième Enquête Démographique et de Santé au Mali.

[7] Belarj, B. (2012) Infants and Child's Jaundice (about 33 Cases). Université Sidi Mohammed Ben Abdhella, Fès. Thèse Med.

[8] Bousfiha, A.A., Mikou, N. and Abid, A. (2000) The Diagnostic of Infants and Child's Jaundice. Esperance med, 7, 92-95.

[9] Bourrillon, A., Chouraqui, J.P., Dehan, M., Lechevallier, J., Chantepie, A., Deslandre, J., et al. (2003) Pediatrics for Practitionners. 5e edition, Masson, Paris, 832 p.

[10] Smahi, M.C., Rahmoun, L., Ghomari, S.M., Benmansour, S., Sendani, H., Bendaddouche, A.S. and Gendrel, D. (2009) Seroprevalence and Risk Factors for Viral Hepatitis A, Tlemcen. Algérie Archi de Pediatrie, 16, 844-846.

https://doi.org/10.1016/S0929-693X(09)74175-2 


\section{Enquiry Form}

1) Identity:

File number:

Date of entry: /

Release Date: /

Last name and First name:

Age:

Sex: $\square \mathrm{M} \square \mathrm{F}$

Tribe:

Address:

\section{2) Medical background}

a) Personal:

Gestational age: Childbirth: $\square$ Medicalized $\square$ Non-medicalized

Birth weight: psychomotor development:

Feeding mode: $\square$ artificial breastfeeding $\square$ breastfeeding $\square$ mixed breastfeeding Expanded Program on Immunization (EPI): $\square$ correct $\square$ Incorrect $\square$ Not done Educated: $\square$ Yes $\square$ No

Known pathology:

Transfusion: $\square$ Yes $\square$ No

Hospitalization antecedent:

Jaundice Antecedent: $\square$ Yes $\square$ No

b) Familial:

Sibling: Consanguinity: $\square 1^{\text {st }}$ degree $\square 2^{\text {nd }}$ degree

Family history of jaundice: $\square$ Yes $\square$ No

3) Reason for consultation:

4) History of the disease:

Start date: /

Installation mode: $\square$ Brutal $\square$ Progressive

Associated signs:

Urine appearance: $\square$ Dark $\square$ clear

Feces appearance: $\square$ discoloured $\square$ normal

Fever: $\square$ yes $\square$ no

Asthenia: $\square$ yes $\square$ no

Weight loss: $\square$ yes $\square$ no

Abdominal pain: $\square$ yes $\square$ no

Digestive disorders: $\square$ yes $\square$ no

pruritus: $\square$ yes $\square$ no

5) Admission examination:

a) General examination:

Weight $(\mathrm{kg})$ :

Size $(\mathrm{cm})$ :

Cranial perimeter $(\mathrm{cm})$ :

Temperature $\left({ }^{\circ} \mathrm{C}\right)$ : 
Heart beat frequency:

Breathing frequency:

General condition: $\square$ good $\square$ fair $\square$ bad

Skin rash: $\square$ yes $\square$ no

Mucocutaneous pallor: $\square$ yes $\square$ no

Conjunctive: $\square$ jaundice $\square$ subicterus

Generalized jaundice (mucous membrane and teguments): $\square$ yes $\square$ no

Discolored stools: $\square$ yes $\square$ no

Dark urine: $\square$ yes $\square$ no

Pruritus: $\square$ yes $\square$ no

b) Examen abdominal:

Hepatomegaly: $\square$ yes $\square$ no

Splenomegaly: $\square$ yes $\square$ no

Abdominal mass: $\square$ yes $\square$ no

Ascites: $\square$ yes $\square$ no

Collateral venous circulation: $\square$ Yes $\square$ No

c) Other:

Psychomotor delay: $\square$ yes $\square$ no

Failure to thrive: $\square$ yes $\square$ no

Associated malformation:

Neurological signs:

Other associated signs:

6) Complementaryexamination:

a) Biological:

Blood count:

Red Blood Cells (RBC) HbHemoglobin

White Blood Cells (WBC) Polynuclear neutrophils platelets

Lymphocyte

Monocytes

Reticulocyte

Mean corpuscular volume

Average Corpuscular Hemoglobin Concentration

Gamma glutamyl transpeptidase (GGT)

Alkaline phosphatase (ALP)

LDH PRTotal BIL

Conjugate BIL

Free BIL

Aminotranferase: ALT AST

Serology

Ac anti HAV

Ac anti $\mathrm{HCV}$

Ac anti $\mathrm{HBc}$

AgHBs

TPHA-VDRL

CMV

Leishmaniasis

Toxoplasmosis

Rubella

Cytobacteriological study of urine

Blood culture

Blood smear 
Electrophoresis of Hemoglobin EPP

Rate of G6PD

Myelogram

THS

Liver function

Liver biopsy puncture

Ascite puncture

Other:

b) Radiologiques:

Chest X-ray

Abdominal ultrasound

Echocardiography

Abdominal CT

Digestiveendoscopy

Cholangiography

CT cholangiography

Cholecystography

Other:

7) Diagnostic selected:

\section{8) Complications:}

\section{9) Care:}

Symptomatic:

Etiologic:

Medical:

Surgical:

\section{0) Duration of hospitalization:}

11) Evolution:

Full recovery: $\square$ yes $\square$ No

Chronic evolution and secondary complication:

Cholestasis: $\square$ decreased $\square$ aggravated $\square$ stabilized

Edema-ascitic Syndrome: $\square$ HTP Portal hypertension $\square$ IHC Hepatocellular insufficiency $\square$ Infection $\square$ Cirrhosis

Sequelae:

Death: 